\title{
National numbers on academic libraries
}

\author{
By Mary Jo Lynch
}

\section{An IPEDS update}

$\mathbf{H}$ ow much do you know about academic libraries in the U.S.? What would you do if someone asked you the following questions?

- How many people work in academic libraries nationwide? In our state?

- How much do academic libraries spend nationwide? What about our state?

- How many volumes were added to academic libraries nationwide? In our state?

- How many serial subscriptions are held by academic libraries nationwide? In our state?

Answers to the first question in each set can be found in the sidebar. Answers to all of them and more can be found in Academic Libraries: 1990 soon to be published by the National Center for Education Statistics (NCES). It is already available on the Office for Educational Research Improvement Electronic Bulletin Board; call (800) 222-4922 for information.

Long overdue, this report on libraries in 3,274 academic institutions is the first result of a new process that will result in more timely reports in the future. This is what has happened:

1) In response to a 1985 National Research Council report that was very critical of NCES, the agency made many improvements in its overall program.

2) Because libraries were mentioned specifically in the section on NCES in the HawkinsStafford School Improvement Act of 1988, NCES is taking a special interest in library statistics and has established a Library Statistics Unit within its Postsecondary Education Statistics Division.

3) The Office of Management and Budget (OMB) now allows NCES to collect academic library statistics every two years (instead of every four years).

4) A system of library representatives has been established whereby a librarian in each state has agreed to help NCES with the biennial data collection.

5) Data are submitted to NCES on disk and aggregated/analyzed by microcomputer.

6) The form and instructions have been revised in response to suggestions from the library community.

To understand the NCES academic library statistics, it is important to remember that they are collected by NCES as one component of the Integrated Postsecondary Education Data System (IPEDS) that obtains data on all aspects of postsecondary education (providers, participants, completions, programs, resources). Nine periodic surveys are conducted in IPEDS-some annual, some biennial.

IPEDS relies on a network of state coordinators to distribute forms to campuses and ensure their return to NCES. These coordinators are usually in the state agency that coordinates higher education. In some states, the responsibility is shared by several agencies, each concerned with a different "sector" of higher education (i.e., different level of degree or type of control). Typically, forms are sent from NCES to the state agency to the campus office responsible for institutional research. The route back to NCES reverses the distribution route, (i.e., campus to state agency to NCES).

For years the academic library community has been frustrated by IPEDS partly because it takes so long to get published results. The changes just described should speed things considerably so that questions like those asked above can be answered with up-to-date data. Several of the changes have been facilitated by 

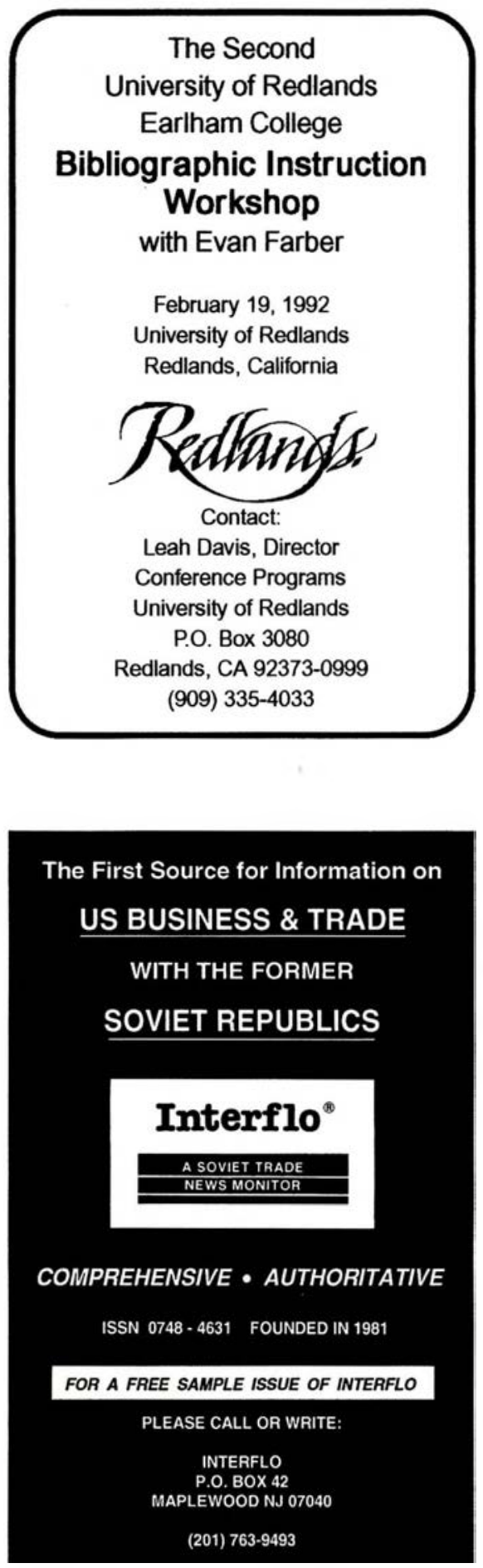

a two-year project based in the ALA Office for Research and Statistics (ORS) and advised by a committee of ACRL members. ${ }^{1}$ In the future a restructured committee will meet twice a year, under the auspices of the ORS, to help NCES keep improving all aspects of the academic library survey form and procedures. Contact the author with your comments or suggestions at (800) 545-2433, ext. 4273 (office) or (312) 2803256 (fax).

Ed. note: Results of the 1990 survey are available in print and on diskette. Order Academic Libraries: 1990 from the Government Printing Office. Order the diskette from the Department of Education Information Technology Branch, (202) 219-1847. If you have questions call Jeff Williams at NCES at (202) 219-1362.

\section{Note}

${ }^{1}$ Serving on the Advisory Committee were librarians selected in cooperation with ACRL and the Association of Research Libraries (ARL): Susan Brant, Nicolet Area Technical College; Paul Dumont, Dallas County Community College District; Kent Hendrickson, Univ, of Nebraska; Ronald Naylor, Univ. of Miami; Eleanor Pinkham, Kalamazoo College; Sarah Pritchard, ARL (now Smith College); and Kendon Stubbs, Univ. of Virginia. The project director was Mary Jo Lynch. Keith Lance of the Colorado State Library served as consultant-recorder.

\section{Key statistics from} Academic Libraries: 1990

Staff

$\begin{array}{lr}\text { National } & 99,683 \\ \text { Highest State (CA) } & 11,073 \\ \text { Lowest State (WY) } & 209\end{array}$

\section{Spending}

$\begin{array}{lr}\text { National } & \$ 3,257,813,000 \\ \text { Highest State (CA) } & 332,228,000 \\ \text { Lowest State (WY) } & 7,341,000\end{array}$

\section{Volumes added}
National
$19,002,705$
Highest State (CA)
$1,697,050$
41,760
Lowest State (MT)
41,760
Serial subscriptions held
National
$5,749,449$
Highest State (CA)
610,747
Lowest State (NV)
12,162

